ORIGINAL ARTICLE

PRACA ORYGINALNA

\title{
TIME COURSE OF ENDOTHELIAL DYSFUNCTION AND ATHEROTHROMBOSIS MARKERS IN PATIENTS WITH ACUTE MYOCARDIAL INFARCTION WITH ST SEGMENT ELEVATION AND TYPE 2 DIABETES MELLITUS DEPENDING ON REPERFUSION THERAPY APPROACH
}

DOI: 10.36740/WLek202001124

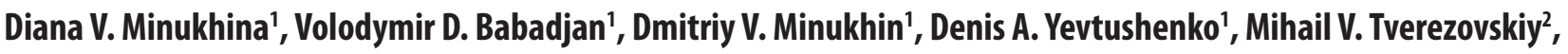 \\ Oleksandr M. Kudrevych ${ }^{3}$ \\ 'KHARKIV NATIONAL MEDICAL UNIVERSITY, KHARKIV, UKRAINE \\ ${ }^{2}$ MILITARY ACADEMY, ODESA, UKRAINE \\ 3V. N. KARAZIN KHARKIV NATIONAL UNIVERSITY, KHARKIV, UKRAINE
}

\begin{abstract}
The aim: To evaluate the levels of plasminogen activator type 1 inhibitor, asymmetric dimethylarginine and endothelial nitric oxide synthase on day 10-14 in patients, depending on the presence or absence of concomitant type 2 diabetes and the type of reperfusion therapy.

Materials and methods: The study involved 130 patients with acute myocardial infarction, divided into 2 groups: Group 1 consisted of patients with acute myocardial infarction with type 2 diabetes mellitus ( $n=73$ ), Group 2 comprised patients with acute type 2 diabetes mellitus ( $n=57)$. The quantitative content of IAP-1 was determined by enzymelinked immunosorbent assay using a commercial test system manufactured by Technoclone PAI-1 ELISA Kit (Austria), NOS - Enzyme-Linked Immunosorbent Assay (ELISA) Kit for Nitric Oxide Synthase Endothelial (NOS) ADMA ELISA Kit (Austria).

Results and conclusions: Percutaneous coronary intervention contributes to a significant reduction in the content of ADMA, which is a marker of endothelial dysfunction and increase NOS on the 10-14th day of acute myocardial infarction compared with standard therapy. During PCI, the level of IAP-1 did not significantly change in the time course of treatment due to post-inflammatory and post-traumatic activation of platelets in the vascular wall.
\end{abstract}

KEY WORDS: acute myocardial infarction, type 2 diabetes mellitus, endothelial dysfunction, asymmetric dimethylarginine, plasminogen activator inhibitor type 1, percutaneous coronary intervention

\section{INTRODUCTION}

Coronary heart disease (CHD) is the leading disease in the circulatory system [1]: in Europe, it accounts for about 38\% of the prevalence rate and $19.5 \%$ of overall mortality [2]. Despite some advances in the study of pathogenesis, diagnosis and especially treatment, including the widespread use of various methods of revascularization, disability and lethality in this disease remains extremely high. Acute myocardial infarction remains the leading cause of disability leading in mortality worldwide.

It is impossible to underestimate the impact of type 2 diabetes on the incidence of acute myocardial infarction, which is higher than the average in the population and the prognosis of life in such patients is much worse than that in patients without disorders of carbohydrate metabolism [3].

Endothelial dysfunction is a crucial factor among many pathogenic mechanisms of vascular injury in ischemic heart disease and type 2 diabetes $[4,5]$, in which inflammation and endothelial dysfunction play an important role in the development of MI $[6,7,8,9]$.
According to current data, in addition to these factors, a major role in the development of cardiovascular complications of diabetes belongs to the reduction of fibrinolytic activity $[10,11]$, which is associated with an increase in the concentration and activity of plasminogen activator inhibitor type 1 (IAP-1) [12 ].

Inhibition of fibrinolysis is due to a number of factors that are able to directly bind plasmin or retard plasminogen activation. One of the main inhibitors of fibrinolysis is IAP-1 (also called endothelial type of inhibitor), which is constantly produced and secreted by endothelial cells.

Scientific literature suggests that plasminogen activator inhibitor type 1 is involved not only in the metabolic processes of atherosclerosis, causing thrombosis, but also in the development of type 2 diabetes $[13,14]$. However, due to the fact that there are conflicting data on the concentration of this marker in the time course of treatment [15], in our study we analyzed the time course of IAP-1 levels in the presence of a combined pathology of acute myocardial infarction and type 2 diabetes, depending on therapeutic approach. 
Endothelial dysfunction is considered a key link in the pathogenesis of microvascular complications of diabetes. Disruption of endothelium-dependent vasodilation is one of the main effects arising from the accumulation of asymmetric dimethylarginine (ADMA), an endogenous inhibitor of endothelial nitric oxide synthase - NOS, which is formed in the process of methylation of the amino acid L-17].

ADMA is currently being studied as a marker of endothelial dysfunction [18].

To date, percutaneous coronary intervention (PCI) has been widely implemented in the practice of endovascular ACS treatment, which is a lifesaving procedure and the best reperfusion method for acute myocardial infarction with ST segment elevation [19]. Numerous factors contributing to the development of acute coronary events after stenting have been extensively discussed in the literature $[20,21]$.

\section{THE AIM}

To assess the time course of levels of plasminogen activator inhibitor type 1, asymmetric dimethylarginine and endothelial nitric oxide synthase on day 10-14 in patients, depending on the presence or absence of concomitant type 2 diabetes mellitus and the selected therapeutic approach, namely percutaneous coronary intervention (coronary stenting) or low molecular weight heparin therapy in combination with dual antiplatelet therapy.

\section{MATERIALS AND METHODS}

The study involved 130 patients with acute myocardial infarction who were hospitalized in the infarction department of Kharkiv City Clinical Hospital No. 27, Intensive Care Unit and Cardiology Department of the municipal non-profit enterprise of Kharkiv Regional Council "Regional Clinical Hospital" and the Department of Interventional Cardiology of V.T. Zaitsev Institute of General and Urgent Surgery of the Institute of National Academy of Medical Sciences of Ukraine. All patients were divided into 2 groups: Group 1 included patients with acute myocardial infarction with type 2 diabetes mellitus ( $n=73$ ), Group 2 comprised patients with acute type 2 diabetes mellitus $(\mathrm{n}=57)$. Group 1 included 43 men $(41.7 \%)$ and 30 women (58.3\%); Group 2 included 43 men (70.9\%) and 14 women (29.1\%). The mean age of patients in Group 1 was $62.73 \pm 1.40$ years, and in Group $263.98 \pm 1.47$ years. The control group consisted of 20 practically healthy individuals, whose average age was $60.85 \pm 0.17$ years.

The quantitative content of IAP-1 was determined by enzyme-linked immunosorbent assay using a commercial test system manufactured by Technoclone PAI-1 ELISA Kit (Austria), NOS by Enzyme-Linked Immunosorbent Assay (ELISA) Kit for Nitric Oxide Synthase Endothelial (NOS), Asymmetric Dimethylarginine - Immunodiagnostik ADMA ELISA Kit (Austria).

Four subgroups of patients were formed for comparative evaluation of the therapeutic effect of combination therapy in acute myocardial infarction: 1st subgroup of patients with acute type 2 diabetes mellitus who underwent PCI (coronary stenting) ( $\mathrm{n}=58)$; 2 nd subgroup of patients with AMI with type 2 diabetes, who underwent standard anticoagulation therapy with enoxaparin/fondaparinux in combination with dual antiplatelet therapy $(\mathrm{n}=15)$; 3 rd subgroup of patients with AMI without type 2 diabetes who underwent PCI $(\mathrm{n}=40)$; 4th subgroup $(\mathrm{n}=17)$ comprised patients with AMI without type 2 diabetes who underwent standard anticoagulation therapy.

Mathematical computer processing of the results was performed using the software Statistica 6.0 (StaSoft Inc, USA). We calculated: mean (M), variance, standard deviation, median $(\mathrm{m})$, probability and significance level (p). For comparative analysis of the samples with normal distribution, the significance of the differences was confirmed using the Student's $t$ test $(t)$ and a standard correlation analysis program with the calculation of arithmetic mean values: $M+m, \sigma$, probability and confidence level (p). Non-parametric Mann-Whitney test was used for pairwise comparisons of the means in the groups. Non-parametric paired Wilcoxon test was used in the analysis of samples not subject to the Gaussian distribution laws.

\section{RESULTS AND DISCUSSION}

Patients with concomitant type 2 diabetes (Table I) on day 1 of acute myocardial infarction with ST segment elevation were found to have significantly higher levels of IAP-1 compared with patients without concomitant diabetes mellitus $(62.38 \pm 1.83 \mathrm{ng} / \mathrm{ml})$ and $50.99 \pm 2.01 \mathrm{ng} / \mathrm{ml}$; $66.72 \pm 1.63 \mathrm{ng} / \mathrm{ml}$ and $51.11 \pm 3.03 \mathrm{ng} / \mathrm{ml}$, respectively; $\mathrm{p}<0.001)$. These findings suggest that patients on day 1 of AMI in conditions of acute occlusion of the coronary artery secondary to insulin resistance have a greater tendency to thrombosis, compared with patients without disorders of carbohydrate metabolism.

On day 10-14 of AMI in the group of patients with type 2 diabetes, there was no significant decrease in the level of IAP- 1 compared with the results on day 1 , as with stenting $(62.38 \pm 1.83 \mathrm{ng} / \mathrm{ml}$ and $61.75 \pm 1.81 \mathrm{ng} / \mathrm{ml}$, respectively; $\mathrm{p}>0.05)$, and when using standard antiplatelet therapy $(66.72 \pm 1.63 \mathrm{ng} / \mathrm{ml}$ and $60.78 \pm 0.90 \mathrm{ng} / \mathrm{ml}$, respectively; $\mathrm{p}>0.05$ ), which may indicate a prolonged risk of thrombus formation secondary to insulin resistance.

In patients with type 2 diabetes mellitus on day 10-14 of treatment, there was a significant decrease in serum IAP-1 in patients both with PCI $(50.99 \pm 2.01 \mathrm{ng} / \mathrm{ml}$ and $45.55 \pm 1.88 \mathrm{ng} / \mathrm{ml} ; \mathrm{p}<0.05)$ and when using standard antithrombotic therapy $(51.11 \pm 3.03 \mathrm{ng} / \mathrm{ml}$ and $42.63 \pm$ $1.94 \mathrm{ng} / \mathrm{ml} ; \mathrm{p}<0.05)$.

According to the results of our study (Table II), significantly higher levels of ADMA were observed in patients with concomitant type 2 diabetes mellitus on day 1 , regardless of treatment tactics $(1.031 \pm 0.038 \mu \mathrm{mol} / \mathrm{l}$ and $0.57 \pm$ $0.025 \mu \mathrm{mol} / \mathrm{l} ; 1.063 \pm 0.06 \mu \mathrm{mol} / \mathrm{l}$ and $0.62 \pm 0.029 \mu \mathrm{mol} / \mathrm{l}$, respectively; $\mathrm{p}<0.001$ ).

In the study of ADMA on day 10-14 of AMI there was a significant decrease in the level of ADMA in comparison with the results on day 1 of AMI, both with stenting and 
Table I. Time course of IAP-1 levels on day 1 and day 10-14 of acute myocardial infarction, depending on the chosen therapeutic approach

\begin{tabular}{|c|c|c|c|c|c|}
\hline \multirow{3}{*}{$\begin{array}{l}\text { IAP-1 level, } \\
\mathrm{ng} / \mathrm{ml}\end{array}$} & \multicolumn{2}{|c|}{$\begin{array}{l}\text { Patients with acute myocardial infarction } \\
\text { with concomitant type } 2 \text { diabetes, } n=73\end{array}$} & \multicolumn{2}{|c|}{$\begin{array}{l}\text { Patients with acute myocardial } \\
\text { infarction, } n=57\end{array}$} & \multirow{3}{*}{$\mathbf{p}$} \\
\hline & $\begin{array}{l}\text { With stenting, } \\
\quad \mathrm{n}=\mathbf{5 8}\end{array}$ & $\begin{array}{l}\text { Without stenting, } \\
\qquad n=15\end{array}$ & $\begin{array}{l}\text { With stenting, } \\
\qquad \mathrm{n}=\mathbf{4 0}\end{array}$ & $\begin{array}{l}\text { Without stenting, } \\
\qquad \mathrm{n}=\mathbf{1 7}\end{array}$ & \\
\hline & 1 & 2 & 3 & 4 & \\
\hline Day 1 of AMI & $62.38 \pm 1.83^{*}$ & $66.72 \pm 1.63^{* *}$ & $50.99 \pm 2.01 \wedge$ & $51.11 \pm 3.03 "$ & $\begin{array}{l}\mathrm{p}_{1-2}>0.05 \\
\mathrm{p}_{3-4}>0.05 \\
\mathrm{p}_{1-3}<0.001 \\
\mathrm{p}_{2-4}<0.001\end{array}$ \\
\hline $\begin{array}{l}\text { Day } 10-14 \\
\text { of AMI }\end{array}$ & $61.75 \pm 1.81^{*}$ & $60.78 \pm 0.90^{* *}$ & $45.55 \pm 1.88^{\wedge}$ & $42.63 \pm 1.94 "$ & $\begin{array}{l}\mathrm{p}_{1-2}>0.05 \\
\mathrm{p}_{3-4}>0.05 \\
\mathrm{p}_{1-3}<0.001 \\
\mathrm{p}_{2-4}<0.001\end{array}$ \\
\hline
\end{tabular}

Note: ${ }^{*},{ }^{* *}$ - statistical significance of differences $p>0.05 ; \wedge, "$ - statistical significance of differences $p<0.05$.

Table II. Time course of ADMA level on day 1 and 10-14 of acute myocardial infarction depending on the chosen therapeutic approach

\begin{tabular}{|c|c|c|c|c|c|}
\hline \multirow{3}{*}{$\begin{array}{l}\text { ADMA level, } \\
\mu \mathrm{mol} / \mathrm{l}\end{array}$} & \multicolumn{2}{|c|}{$\begin{array}{l}\text { Patients with acute myocardial infarction } \\
\text { with concomitant type } 2 \text { diabetes, } n=73\end{array}$} & \multicolumn{2}{|c|}{$\begin{array}{l}\text { Patients with acute myocardial } \\
\text { infarction, } n=57\end{array}$} & \multirow{3}{*}{$\mathbf{p}$} \\
\hline & $\begin{array}{l}\text { With stenting, } \\
\quad \mathrm{n}=\mathbf{5 8}\end{array}$ & $\begin{array}{l}\text { Without stenting, } \\
\mathrm{n}=\mathbf{1 5}\end{array}$ & $\begin{array}{l}\text { With stenting, } \\
\quad \mathrm{n}=\mathbf{4 0}\end{array}$ & $\begin{array}{l}\text { Without stenting, } \\
\qquad \mathrm{n}=17\end{array}$ & \\
\hline & 1 & 2 & 3 & 4 & \\
\hline Day 1 of AMI & $1.03 \pm 0.04^{*}$ & $1.06 \pm 0.06^{* *}$ & $0.57 \pm 0.03^{\times}$ & $0.62 \pm 0.02^{\wedge}$ & $\begin{array}{l}\mathrm{p}_{1-2}>0.05 \\
\mathrm{p}_{3-4}>0.05 \\
\mathrm{p}_{1-3}<0.001 \\
\mathrm{p}_{2-4}<0.001\end{array}$ \\
\hline Day 10-14-й of AMI & $0.84 \pm 0.03^{*}$ & $0.87 \pm 0.05^{* *}$ & $0.51 \pm 0.03^{x}$ & $0.45 \pm 0.04 \wedge$ & $\begin{array}{l}\mathrm{p}_{1-2}>0.05 \\
\mathrm{p}_{3-4}>0.05 \\
\mathrm{p}_{1-3}<0.001 \\
\mathrm{p}_{2-4}<0.05\end{array}$ \\
\hline
\end{tabular}

Note: ${ }^{*}{ }^{* *},{ }^{\times}, \wedge$ - statistical significance of differences, $\mathrm{p}<0.05$.

Table III. Time course of the level of NOS on day 1 and 10-14 of acute myocardial infarction, depending on the chosen therapeutic approach

\begin{tabular}{|c|c|c|c|c|c|}
\hline \multirow{3}{*}{ NOS level, ng/ml } & \multicolumn{2}{|c|}{$\begin{array}{l}\text { Patients with acute myocardial infarction } \\
\text { with concomitant type } 2 \text { diabetes, } n=73\end{array}$} & \multicolumn{2}{|c|}{$\begin{array}{l}\text { Patients with acute myocardial infarction, } \\
\qquad n=57\end{array}$} & \multirow{3}{*}{$\mathbf{p}$} \\
\hline & $\begin{array}{l}\text { With stenting, } \\
\quad \mathrm{n}=\mathbf{5 8}\end{array}$ & $\begin{array}{l}\text { Without stenting, } \\
\qquad n=15\end{array}$ & $\begin{array}{l}\text { With stenting, } \\
\qquad \mathrm{n}=\mathbf{4 0}\end{array}$ & $\begin{array}{l}\text { Without stenting, } \\
\qquad n=17\end{array}$ & \\
\hline & 1 & 2 & 3 & 4 & \\
\hline Day 1 of AMI & $3.10 \pm 0.16^{*}$ & $3.22 \pm 0.35^{* *}$ & $4.26 \pm 0.13^{\times}$ & $4.15 \pm 0.23 \wedge$ & $\begin{array}{l}\mathrm{p}_{1-2}>0.05 \\
\mathrm{p}_{3-4}>0.05 \\
\mathrm{p}_{1-3}<0.001 \\
\mathrm{p}_{2-4}<0.05\end{array}$ \\
\hline Day 10-14 of AMI & $4.81 \pm 0.15^{*}$ & $4.61 \pm 0.19^{* *}$ & $7.42 \pm 0.57^{\times}$ & $9.14 \pm 1.04 \wedge$ & $\begin{array}{l}\mathrm{p}_{1-2}>0.05 \\
\mathrm{p}_{3-4}>0.05 \\
\mathrm{p}_{1-3}<0.001 \\
\mathrm{p}_{2-4}<0.001\end{array}$ \\
\hline
\end{tabular}

Note:* ${ }^{* *},{ }^{*}, \wedge-$ Statistical significance of differences, $p<0.05$.

without stenting of coronary arteries in groups of patients with type 2 diabetes $(1.03 \pm 0.04$ and $0.84 \pm 0.03 \mu \mathrm{mol} / \mathrm{l}$ $1.06 \pm 0.06$ and $0.87 \pm 0.05 \mu \mathrm{mol} / \mathrm{l})$, and without $(0.57 \pm 0.03$ and $0.51 \pm 0.03 \mu \mathrm{mol} / \mathrm{l} ; 0.62 \pm 0.02$ and $0.45 \pm 0.04 \mu \mathrm{mol} / \mathrm{l}$, respectively; $\mathrm{p}<0.05)$, while in patients with type 2 diabetes, ADMA levels remained significantly higher than in patients without type 2 diabetes regardless of therapeutic approach
$(0.84 \pm 0.03 \mu \mathrm{mol} / 1 ; 0.87 \pm 0.05 \mu \mathrm{mol} / \mathrm{l} ; 0.51 \pm 0.03 \mu \mathrm{mol} / \mathrm{l} ; 0.45 \pm$ $0.04 \mu \mathrm{mol} / 1$ respectively; p1-2,3-4>0.05, p1-3<0.001, p2-4<0.05).

The data obtained indicate a positive effect of CA stenting and standard therapy on the time course of asymmetric dimethylarginine in these categories of patients, which is confirmed by a significant decrease in ADMA in the time course of AMI within 10-14 days after treatment. 
The value of endothelial oxidative stress in the progression of ischemic coronary artery disease in acute myocardial infarction cannot be underestimated, so we analyzed the levels of endothelial nitric oxide synthase in this cohort of patients.

Our study showed (Table III) that patients on day 1 of AMI with concomitant type 2 diabetes had significantly lower NOS levels compared with patients without type 2 diabetes, as in subgroups with CA stenting $(3.10 \pm 0.16 \mathrm{ng} / \mathrm{ml}$ and $4.26 \pm 0.13 \mathrm{ng} / \mathrm{ml}$, respectively; $\mathrm{p}<0.001)$ and during standard anticoagulant and dual antiplatelet therapy $(3.22$ $\pm 0.35 \mathrm{ng} / \mathrm{ml}$ and $4.15 \pm 0.23 \mathrm{ng} / \mathrm{ml}$, respectively; $\mathrm{p}<0.05$ ), which indicates the suppression of the anti-ischemic barrier of the endothelium secondary to insulin resistance observed in the majority of patients with type 2 diabetes.

On day 10-14 of acute myocardial infarction there was a significant increase in the level of NOS, regardless of the therapeutic approach, both in patients with concomitant type 2 diabetes and without diabetes, but in patients with type 2 diabetes less intense $(4.82 \pm 0.31$ and $4.61 \pm 0.42$ $\mathrm{ng} / \mathrm{ml} ; 7.42 \pm 0.57 \mathrm{ng} / \mathrm{ml} ; 9.14 \pm 1.04 \mathrm{ng} / \mathrm{ml}$, respectively; p1-2>0.05, p3-4 >0.05, p1-3.2-4<0.001).

This indicates a gradual recovery of endothelial function secondary to the positive effects of treatment, especially in patients without disorders of carbohydrate metabolism.

The restoration of endothelial function in the early post-infarction period in patients with type 2 diabetes and without it is evidenced by a statistically significant decrease in the marker of endothelial dysfunction of ADMA and an increase in the concentration of endothelial nitric oxide synthase by the 10-14th day of AMI in all the examined patients both with CA stenting, as well as following standard therapy and the presence of concomitant pathology in the form of type 2 diabetes. In patients with type 2 diabetes mellitus ADMA levels remained significantly higher than in patients without type 2 diabetes mellitus, irrespective of therapeutic approach indicating a decrease, but a significant excess of the normative values of endothelial dysfunction processes, compared with patients with AMI without type 2 diabetes mellitus in early post-infarction period.

Regarding the level of the thrombus formation marker IAP-1, in patients with AMI with ST segment elevation, an increase in the concentration of IAP-1 in both groups of patients was detected, and the presence of type 2 diabetes defined higher values of this indicator during the first day after ST elevation. At the same time, in the early recovery period of AMI with ST segment elevation in patients without disorders of carbohydrate metabolism, there was a significant decrease in the level of IAP-1, indicating a decrease in the inhibitory effect of IAP-1 and improved fibrinolytic activity of the blood secondary to treatment. Patients with type 2 diabetes in the early recovery period after AMI (10-14 days after treatment) had persistently $(p<0.001)$ higher level of IAP-1. The obtained data also suggest that patients with acute myocardial infarction with ST segment elevation within 10-14 days after PCI have a prolonged nature of increased serum IAP-1 concentration due to the inflammatory consequences of post-procedural activation of platelets and decreased function of endogenic thrombolytic system.

\section{CONCLUSIONS}

1. In patients with acute myocardial infarction with type 2 diabetes, percutaneous coronary intervention contributes to a significant decrease in asymmetric dimethylarginine content and an increase in NOS on the 10-14th day of acute myocardial infarction, indicating a positive effect of the performed revascularization.

2. Percutaneous coronary intervention in patients with AMI with ST-segment elevation and type 2 diabetes was not accompanied by a significant decrease in IAP- 1 level by day 10-14 of AMI, which suggests a prolonged nature of increased serum IAP-1 concentration due to inflammatory consequences of post-procedural platelet activation and decreased endogenous thrombolytic system functioning.

\section{REFERENCES}

1. Grasgruber P, Sebera M, Hrazdira E, et al. Food consumption and the actual statistics of cardiovascular diseases: an epidemiological comparison of 42 European countries. Food Nutr Res. 2016Sep 27;60:31694. doi: 10.3402/ fnr.v60.31694. PMID: 27680091 PMCID: PMC5040825.

2. Timmis A, Townsend N, Gale C, et al. Eur Heart J. 2018 Feb 14;39(7):508579. doi: 10.1093/eurheartj/ehx628. PMID: 29190377.

3. Barkoudah E, Skali H, Uno H, et al. Mortality rates in trials of subjects with type 2 diabetes. J. Am. Heart Assoc. 2012 Feb;1(1):8-15. doi: 10.1161/ JAHA.111.000059. PMCID: PMC3487314. PMID: 23130114.

4. Matsuzawa Y, Lerman A. Endothelial dysfunction and coronary artery disease: assessment, prognosis, and treatment. Coron Artery Dis 2014 Dec; 25(8):713-24. doi: 10.1097/MCA.0000000000000178. PubMed PMID: 25365643; PubMed Central. PMCID: PMC4220301.

5. Huang Y, Cai X, Mai W, et al. Association between prediabetes and risk of cardiovascular disease and all cause mortality: systematic review and meta-analysis. BMJ; 2016 Nov 23;355:15953. doi: 10.1136/bmj.i5953. PubMed PMID: 27881363; PubMed Central PMCID: PMC5121106.

6. Bohlen HG. Nitric oxide and the cardiovascular system. Compr Physio 2015 Apr; 5(2):808-23. doi: 10.1002/cphy.c140052. PubMed PMID: 25880514.

7. Lee CW, Ahn JM, Cavalcante R, et al. Coronary Artery Bypass Surgery Versus Drug-Eluting Stent Implantation for Left Main or Multivessel Coronary Artery Disease: A Meta-Analysis of Individual Patient Data. JACC Cardiovasc Interv. 2016 Dec 26;9(24):2481-9. doi: 10.1016/j. jcin.2016.10.008. PMID: 28007199.

8. Gaiz A, Mosawy S, Colson N, Singh I. Thrombotic and cardiovascular risks in type two diabetes; Role of platelet hyperactivity. Biomed Pharmacother. 20170ct;94:679-86. doi: 10.1016/j.biopha.2017.07.121. PubMed PMID: 28787703.

9. Navinan MR, Mendis S, Wickramasinghe S, et al. Inflammation in STelevation myocardial infarction: risk factors, patterns of presentation and association with clinical picture and outcome, an observational study conducted at the Institute of Cardiology-National Hospital of Sri Lanka. BMC Cardiovasc Disord. 2019 May 14;19(1):111. doi: 10.1186/ s12872-019-1104-5. PMCID: PMC6518612. PMID: 31088357.

10. Schiele F, Hochadel M, Tubaro M, et al. Reperfusion strategy in Europe: temporal trends in performance measures for reperfusion therapy in STelevation myocardial infarction. Eur Heart J.2010 Nov;31(21):2614-24. doi: 10.1093/eurheartj/ehq305. PMID: 20805111. 
11. Liu F, Guo Q, Xie G, et al. Percutaneous Coronary Intervention after Fibrinolysis for ST-Segment Elevation Myocardial Infarction Patients: An Updated Systematic Review and Meta-Analysis. PLOS ONE 2015 Dec 29; 10(12): e0146207. doi: 10.1371/journal.pone.0141855. PMID: 26523834 PMCID: PMC4629904.

12. Sobel BE, Taatjes DJ, Schneider DJ. Intramural plasminogen activator inhibitor type-1 and coronary atherosclerosis. Arterioscler. Thromb. Vasc. Biol. 2003 Aug 14; 23(11):1979-89. doi:10.1161/01. atv.0000091250.53231.4d.

13. Song C, Burgess S, Eicher JD, et al. Causal Effect of Plasminogen Activator Inhibitor Type 1 on Coronary Heart Disease. J Am Heart Assoc.2017 May 26;6(6). pii: e004918. doi: 10.1161/JAHA.116.004918. PMID: 28550093. PMCID: PMC5669150.

14. Jung RG, Simard $T$, Labinaz $A$, et al. Role of plasminogen activator inhibitor-1 in coronary pathophysiology. Thromb Res. 2018 Apr; 164:5462. doi: 10.1016/j.thromres.2018.02.135. PMID: 29494856.

15. Leibundgut $\mathrm{G}$, Lee JH, Strauss BH, et al. Acute and Long-Term Effect of Percutaneous Coronary Intervention on Serially-Measured Oxidative, Inflammatory, and Coagulation Biomarkers in Patients with Stable Angina.JThromb Thrombolysis. 2016 May; 41(4):569-80. doi:10.1007/ s11239-016-1351-6. PMID: 26964999. PMCID: PMC4811750.

16. Vallance $P$, Leone $A$, Calver $A$, et al. Accumulation of an endogenous inhibitor of nitric oxide synthesis in chronic renal failure. Lancet. 1992 Mar 7;339(8793):572-5. doi: 10.1016/0140-6736(92)90865-z. PMID: 1347093.

17. Vallance P. Importance of asymmetrical dimethylarginine in cardiovascular risk. Lancet. 2001 Dec 22-29;358(9299):2096-7. doi: 10.1016/S0140-6736(01)07229-4. PMID: 11784617.

18. Sibal L, Agarwal SC, Home PD, Boger RH. The Role of Asymmetric Dimethylarginine (ADMA) in Endothelial Dysfunction and Cardiovascular Disease. Curr Cardiol Rev. 2010 May; 6(2):82-90. doi: 10.2174/157340310791162659.PMCID:PMC2892080.PMID: 21532773.

19. Liem AL, van't Hof AW, Hoorntje JC, et al. Influence of treatment delay on infarct size and clinical outcome in patients with acute myocardial infarction treated with primary angioplasty. J Am Coll Cardiol. 1998 Sep;32(3):629-33. doi:10.1016/S0735-1097(98)00280-0. PMID: 9741503.
20. Silber $S$, Albertsson P, Avilés FF, et al. Guidelines for Percutaneous Coronary Interventions. The Task Force for Percutaneous Coronary Interventions of the European Society of Cardiology. Eur Heart J. 2005 Apr;26(8):804-47. doi: 10.1093/eurheartj/ehi138. PMID: 15769784.

21. Siontis GC, Stefanini GG, Mavridis D, et al. Percutaneous coronary interventional strategies for treatment of in-stent restenosis: a network meta-analysis. Lancet. 2015 Aug 15;386(9994):655-64. doi: 10.1016/ S0140-6736(15)60657-2. PMID: 26334160.

\section{ORCID and contributionship:}

Diana V. Minukhina - 0000-0003-4091-5849 A,D

Vladimir. D. Babadzhan - 0000-0002-3939-4209 ${ }^{F}$

Dmitriy V. Minukhin - 0000-0003-3371-1178 C

Denis A. Yevtushenko - 0000-0003-1941-7183 ${ }^{\mathrm{E}}$

Oleksandr M. Kudrevych - 0000-0002-2086-8822 A

Mihail V. Tverezovskiy - 0000-0001-7351-932X ${ }^{B}$

\section{Conflict of interest:}

The Authors declare no conflict of interest

\section{CORRESPONDING AUTHOR Diana V. Minukhina \\ Kharkiv National Medical University \\ 4 Nauky Avenue, 61022, Kharkiv, Ukraine \\ tel: +380938444686 \\ e-mail:minukhinadv@ukr.net.}

Received: 10.09.2019

Accepted: 09.12.2019

A - Work concept and design, B - Data collection and analysis, C - Responsibility for statistical analysis, D-Writing the article, $\mathbf{E}$-Critical review, $\mathbf{F}$ - Final approval of the article 